\title{
CONCEPTUAL FOUNDATIONS OF INNOVATION CLUSTERS DEVELOPMENT
}

\section{КОНЦЕПТУАЛЬНІ ЗАСАДИ РОЗВИТКУ ІННОВАЦІЙНИХ КЛАСТЕРІВ}

The article is devoted to topical issues of regional management development and the accumulation of knowledge on the formation of conceptual bases of the organization and support of innovative clusters. It is proved that the development of innovative and cluster model of Ukrainian economy at the same time takes into account and uses a number of conceptual provisions. These are interrelated provisions of the modern innovation theory, postulates of market economy, methods and technologies of regional management. It is proved that conceptual provisions of innovation clusters development ensure the progress and systemic changes of economic activities in regions, this result is logical and appropriate to such strategic perspectives.

The key problems of the formation of the concept and cluster model in regional and industrial formations with innovative orientation are outlined. The vision of innovative cluster features from the position of integration and organizational processes; industry specialization and market priorities is defined. The idea, goal, objectives, management mechanisms and activities tools, approaches to the evaluating of the effectiveness and efficiency of the cluster are proved. As approaches and technologies of the development it is recommended to recognize: comprehensive and high-quality scientific and information support of decision-making process by authorities; effectiveness control and accounting of positive and negative consequences of current decisions; openness and transparency in collective actions, decision-making taking into account positions of all cluster members; formation of positive impact on the image of the region and the industry. The definition of the key principles of the integrated cluster cooperation is given.

Keywords: innovation, cluster, regional management, innovation management, concept, network.

Relevance of the research topic. Innovative economy as category of management has a certain convention, it formally and informally focused on the recognition and dissemination of innovations , innovative activity, innovative technologies, innovative forms of cooperation and specialization, innovation clusters.

In the system of relations of information economy formation, in Ukraine especially, the place, role and recognition becomes theoretically grounded and practically proven fact of benefits of innovation-oriented economies in the system of economic and social progress. This point of view is defended by scientists, experts in management and economy, leading experts of industry management and others.

World domination of the countries with innovative economies is recognized by the world economic experts and leading consulting firms. In the top ten countries with innovative economies in $2013-2015$ were USA, Canada, Israel, Japan, Germany, Sweden, Finland and others.

The Ukrainian economy's transition to innovation model of development involves the creation of many innovative clusters, focused on the account of existing specialization and cooperation, and also the creation of new knowledge-based industries. The national scientific and technical potential can and should serve as a platform for innovation intensive economic recovery, social sphere, strategically important industries. However, there still a significant problem remains a number of issues - the formation of conceptual bases of innovative clusters development, the recognition of the strategic importance of the formation of a modern institutional environment that motivates and stimulates innovation progress, etc.

Formulation of the goal of the study. The formation and spreading of conceptual foundations of innovation clusters development.

Analysis of recent research sources and publications. Particularly acute in the scientific and scientificmethodological publications for the last 10 years are defined and discussed issues of development and increasing of innovation activity, the need for knowledge system of innovation management, the conceptual basis of innovation clusters development. Scientists recognize that in Ukraine there is a gradual process of formation of national innovative system; documented scientific school of innovation, innovation management; formation of new, practical forms of innovation activities - networks, clusters, corporations, etc.

A significant number of issues of innovation management is considered in works of such scientists as Batchenko L. [1], Vartanova O. [3], Kudrina O. [4], etc.; some questions of conceptual bases formation of 
innovation clusters development efined in the works of Pankova L. [8], Kudrina O. [5], Mindlin Yu. [6], Finahina O. [9]; get the spreading questions of the link between the economic interests of the regions and industries in the system of clustering processes promotion - Pankova L. [7]; formed areas of cooperation and integration with the European Union - Bilozubenko V. [2].

This is the initial stage, its initial period of the regional models formation of innovation orientation, the definition and recognition of relevant scientific fields. In the modern national economy of Ukraine takes place regional diversity, which in its entirety and presents the main components for its development.

But the foundation of the theory and methodology of innovation, innovative work, evaluation of innovative processes inherent in the works of Galbraith [10], they are recognized as the world's knowledge.

The main material. The concept of innovation clusters development is a management instrument in the knowledge system of regional management. Conceptual bases of innovative clusters development is a system of knowledge management that is the basis of intensification of the clustering processes and the spread of modern management technologies of innovative activities. It defines the purpose, main idea, principles, major tasks and directions, mechanisms and instruments of implementation, resources' provision, other management forms of regulation of business environment development and opportunities for its interaction with state and regional authorities in the difficult process of consolidation and harmonization in the implementation of innovation cluster initiatives.

Development of the concept model presupposes the existence of the creative initiative, availability of conflicts, compromises, scenario planning and active changes.

Dynamics of the modeling process in general form can be represented step by step:

Step 1. Discussion and simulation purpose forming.

Step 2. Definition of approaches to building of a model (event-related, process-based, display of market activity or economic activities of participants, etc.). Constructing of abstract model with real information needs.

Step 3. Justification of model resource provision. Generation and testing of the real model.

Step 4. The study (analysis) of the real model functioning.

Step 5. Processing, analysis, interpretation and discussion of the simulation results.

In practice, the modeling system of regional economic systems, complex processes is no an optimal sequence of work with the models. The reasons for such complexity are incorporated:

firstly, in inherent functioning of regional economic systems, i.e. the transfer of the model in the changed cultural environment causes unpredictable violations, conflicts, and perhaps problems of management;

secondly, the inability to fully predict the future of regional economic systems, especially the market environment;

thirdly, the special role is played by creative skills of model developers and its conceptual basis, i.e. the so-called human factor;

fourthly, considerable importance is played by those parameters that are set in this model, their quantitative and qualitative display.

Based on the position of presence of certain and required elements of the cluster, as a form of voluntary association of companies, organizations, educational institutions, which are:

1) located in the same region and have the basic characteristics of territorial unity;

2) have a single market space and in the process of implementation of economic activity are dependent on sphere of production and sale of goods and services;

3 ) have industry specialization and focus in its products on the industrial markets.

The feature of the cluster is the presence of partnerships between its members: manufacturing enterprises, suppliers of equipment and components, specialized production services and aftersale services, scientific-research and educational organizations, etc.

Innovation cluster is a complex dynamic system that is formed by a group of companies and organizations that have theoretical and practical interests in the development and implementation of innovations, have a high potential of scientific knowledge within a particular specialization of economic activities.

Model of innovation cluster is a set of parameters and characteristics of the interaction of participants in the activity of multi-level hierarchical dynamic systems in the conditions of market uncertainty based on the implementation of cluster initiatives. The purpose of modeling - to ensure all cluster members with operational and quality information. 
The model as a part of the institutional order and the regulatory impact is a behavioral and communication characteristics, reflecting the processes traffic of information, signals and intellectual products.

Cluster initiative - in a practical sense, the agreement about joint achievement of certain goals in the system of unified communications and the consolidation and harmonization of economic, scientific or other interests.

In the scientific interpretation modeling assume substantiation and use of scientific principles, in this case the principles of clustering regulation in the system of internal and external environment of the cluster formations to provide management model.

In the author's understanding, management model is a simplified picture of the organization specific and operation of certain business. Management model of cluster is the organization and its mechanisms in the system of cluster initiatives implementing in collective activities, shaping the future space of integration activities, events.

In the structure of any management model, usually at the stage of its formation are determined by the following key provisions: analysis and trends of market development, assumptions and forecasts of economic development, scientific and technological forecasts (within of innovation projects).

Conception of the management model of innovation cluster- improving competitiveness of regional economic complex based on stimulation of innovation cluster initiatives and its implementation in the processes of cluster formation.

The goal is to ensure the realization of accumulated innovation potential of the region and ensure its extended and secure reproduction in the interests of attracting investment and innovation in priority sectors of the region.

The basic principles of administrative activity in the knowledge system of regional management require its implementation within the development and implementation of this concept is:

1. The principle of science, in essence, an innovative orientation in any management system is impossible without a system created by mankind knowledge base. The laws of scientific activity is essentially focused on innovation, scientific and technological progress. Reference point to scientific theory and methodology in management activity is a prerequisite and a precondition for success.

2. The principle of development provides changes in the context of a common purpose and solved communicating problems. Takes into consideration changes in the legal framework, market environment, force majeure event, industrial and internal corporate changes. Involves active use of information potential of all cluster members. The implementation of this management principle is quite difficult in practice, because involves phasing in implementation- analytical, designed, decision making, monitoring and adjustment, as required stages of development and implementation of motivational instruments, etc.

In the management system of enterprises, organizations, educational institutions usually for several years used the classical, administrative oriented methods and management techniques. But the global market space and the world economy is changing constantly. Actively modified information industry, its innovation potential continuously reproduced in large quantities and with new quality characteristics, expanding the boundaries of the information market and the number of its participants grows in a certain progression. All this must be considered and used for increasing the competitiveness of cluster members. Progress is provided only in the in the process of fundamental decisions and the introduction of new management techniques. This management activities should be focused on monitoring and evaluation of these changes.

It is recommended to recognize such development methods:

Comprehensive and high-quality scientific and information support of process of of authority decisionmaking;

Control over the effectiveness and account of positive and negative consequences of current decisions;

Openness and transparency in collective actions, making decisions with taking into account positions of all cluster members;

Creating a positive impact on the image of the region and the industry.

3. The principle of consistency-the inability to make decisions, to organize the management influence without the consent of all cluster members. Success in achieving the goal is possible only with the accounting of all relations decomposition, its completeness of reflection, purpose to achieving results. Each process or individual management action is considered in the system of relations in connection with others. The attention of managers is focused on the object of management as a unified organism with its own laws and rules of operation. The object is primary, its components are secondary. A comprehensive solution and the ability to use the full real potential of information. 
In the organization of the cluster model there are such questions as:

definition of goal; activities;

determination of requirements to leadership within document fixed boundaries of management

the definition of functional subsystems, its structure, goals and objectives in the overall system management;

identification and analysis of relations between the subsystems, companies, networks and other elements of the management structure;

definition and documentation of the procedure and basic management technologies of functioning and development of the system as a whole.

4. The principle of coordination is aimed at achieving consistency in the management activities for implementation of cluster initiatives, provides effective work of all links of the cluster by establishing a specific, optimal communication, the formation of special management work technologies. y using specific and documented and formally fixed forms of relationships defined interaction between cluster elements. This issue of regulation of information flows, material and human resources provided coordination and harmonization in the implementation of management functions (planning, organization, motivation and control). The most prominent is management activities to coordinate the work of leadership.

5. The principle of effectiveness is focused on target achievement of results defined in the cluster initiatives. This creation of a system with targeted management, economic, social, environmental, cultural, educational effects, determination and declaration of specific final results in all areas of management activities. In general, must be observed the rule of rational relationship between expenses for creating and implementing a purpose of functional burden on this cluster model and the functioning effect of the created system (in this case, the information management system).

Successful operation of the cluster is primarily determined by the quality of the set cluster initiatives in the framework of the created model creates a system able to function under its constant development, a innovation orientation nd improvement.

6. The principle of hierarchy in the construction and subordination of goals, objectives, activities, priorities and actions, using communications and data sources, formation of responsibility within the plans and programs of cluster initiatives implementation.

The peculiarity and distinctive feature of the action of this principle in the system of management mechanisms of the cluster is their focus on cluster core in the organizational model. In the action of the mechanisms and instruments of management activities is a priority of non economic and social interests of the cluster members, it is directly implementation of cluster initiatives as a result of the effect of management activities.

7. The principle of modernity implies the compliance of management policies, setting of cluster initiatives, the prospects for the development of markets, industries, regional management. Active promotion in decision making of the most modern, technically and technologically advanced communications network, local and global levels.

So at all levels of communication in local and global networks established standards of information culture in the form of regulations, technologies of business processes, organization of interaction with global networks. In building the organizational and thematic cluster model there are management activities:

- The organization of processes, procedures, regulations, technologies of measures to protect the information;

- Regulation of communication processes;

- The definition of information culture standards.

Special attention and approval required standards of information culture. Recommended the most popular elements:

rules for working with documents;

check corporate email;

correctness in organization of communications, forming mail, messages, letters, etc.;

providing feedback systems, etc.

8. The principle of consolidation in the mechanisms and instruments to achieve the objectives and consideration of the interests and demands of the different levels of management as a management guide in implementation of mechanisms and tools of development and consolidation of interests for joint realization of cluster initiatives. This principle is to some extent built on the implementation of interest conflict, because 
many members of the cluster can have common economic and social interests and be market competitors. In practice, the effect of this principle extends to information activities, management technologies, market operations, etc.

9. The principle of completeness administrative mechanisms and instruments, orientation on its redundancy and the ability to solve not only current but also future tasks. With the development of information society whole spectrum of completeness and redundancy of management mechanisms and instruments creates conditions for the progress of management activities.

10. The principle of confidentiality in matters of general management, characteristics of enterprises work and organizations of the cluster, the organization and internal content of the cluster model, cluster initiatives and instruments and mechanisms for development. This issue is directly related to the development and implementation of innovation and innovative technologies, sources of financing, the volume of expenditures and other financial aspects of business.

11. The principle of compatibility suggests that in the framework of used mechanisms and instruments of the developed model focus on the maximum possibility of interaction between cluster members, different levels of management systems, authorities, business partners, market infrastructure and others in the process of the markets functioning.

12. The principle of standardization and unification focused on using existing, standard, documented and underlying technologies, decisions, the relevant requirements of the European Union, the World market. Use of standard software products, databases, special documentation, organizational techniques.

13. The principle of integration aimed at the formation of the uniting managerial interactions, development and functioning of unified management and technological process, development of unified procedures for collecting, processing, systematization and transfer, storage of information, unity and commonality of approaches in making managerial decisions.

14. The principle of adaptability to the changing conditions of internal and external environment within the cluster, changes in scientific-technical and managerial progress, market situations, the demands of consumers, contractors and other changes.

15. The unity of the information space in achieving the objectives of cluster initiatives, solving current problems, making managerial decisions is determined by developing a system of indicators, which exclude any possibility of uncoordinated actions and output incorrect information.

16. The principle of openness of the system (to supplement the information, data, market benchmarks and indicators of the industry development, individual segments and processes of the market environment, competitors, etc.).

Also to the active adaptation are subject to the principles of the relevant structural properties of complex dynamic systems: causality, demonstrativeness, controllability, coordination of interests, collective decisions.

Also in this regard, actualized necessity of using modern principles of functional-spatial planning and economic-mathematical forecasting that take into account regional differences and regularities of social, economic and environmental development of the territory.

Outline the recommended tasks within the framework of the activities of the innovation cluster:

Prioritization of innovation clustering process;

The study, analysis of the world tendencies of the industry development;

Development of innovations in logistics, transport marketing;

Formation business packages of management innovation, etc..

Basic mechanisms of the model implementation: organizational, financial and economic, scientifictechnical, market.

Main instruments - management technologies, methodical planning and business forecasting, project management, management analysis and information mapping, etc..

Unlike traditional forms of cooperation and coordination of subjects cluster systems characterized by the following features:

- the presence of business leaders that determine long-term economic, innovation and other strategy of the whole system;

- territorial localization of the main mass of economic entities - members of the cluster system;

- the stability of cooperation relations of business entities - members of the cluster system, which is dominating value of these relationships for most participants;

- long-term coordination of interaction between participants of the system within its business programs and strategic objectives [6]. 
Conclusions. In modern conditions of active promotion and full support of innovation processes both from the theoretical and methodological support, and from the standpoint of adaptation practices opportunities, the sphere of innovation activity should be considered as a priority for economic growth and competitiveness of Ukraine. Development and promotion of innovative technologies contribute to the formation of new innovation-cluster model of post-industrial or information society. In this new model of the social system the center is the information economy, and priorities are integrated of knowledge management and innovation activity.

Development of innovative cluster model of the Ukrainian economy at the same time takes into account and uses a number of conceptual provisions. This is the interrelated provisions of the modern theory of innovation, postulates of market economy, methods and technologies of regional management. That is the conceptual provisions of development of innovation clusters to ensure progress and systemic changes of introduction of economic activities in the region, such result is logical and appropriate to such strategic perspectives.

First. Formation of new opportunities of unique resources unification of different regions of the country based on the actions of the integration administrative law. This integration of information, intellectual and material resources in the system of cluster interactions "government-business-scienceeducation" that will lead to a systematic increase in the integration of science and industry, education and business activity, production and market. Only such union can provide a new quality of internal relationships and interactions between market counterparties and to form new institutions of trust in society.

Second. Recognition and securing of priority role and place of the state in the formation and development of innovative cluster model, its subjectivization and stimulate the transition to a potential capabilities of indirect regulation and support of the market environment, and not direct control and mandatory administration.

Third. Strengthening the innovation orientation of education, public sector enterprises, small and medium businesses. Changes of all components of the economic system that guarantees the development of science and distributing educational technology, actively integrate into the global progress.

Fourth. Priority of methodological bases formation of innovative clusters formation, evaluation of their activities, strategic management and other issues of life activity of these forms of doing business.

These provisions in its own way related to a particular differentiated several areas of development. This is an opportunity for further development of these conceptual positions as a strategic plan for the development of the whole national economy and individual regions. These provisions are not only conceptual in its scientific and comprehensive reflection of scientific and methodical support, but at the same time is a key problem of forming a new model of regional management in terms of translational motion to the European market.

\section{References}

1. Batchenko, L. V., Vasyl'konova, E. O., Hurenko, A. V. et al. (2013), Clusters in the system of the strategy and tactics of regional development [Klastery v systemi stratehiyi ta taktyky rozvytku rehionu], VIK, Donets'k, $287 \mathrm{p}$.

2. Belozubenko, V. S., Gorina, A. O. and Abrashka, O. V. (2013), "The formation of innovation system of the European Union" ["Formirovanie innovatsionnoy sistemyi Evropeyskogo Soyuza"], Biznes-Inform, No 5, pp. 8-12.

3. Vartanova, O. V. and Shester, I. V. (2014), "Benchmarking of innovation potential of industrial enterprise" ["Benchmarkinh innovatsiynoho potentsialu promyslovoho pidpryyemstva"] Naukovyy visnyk Khersons'koho derzhavnoho universytetu. Seriya: Ekonomichni nauky, No 8, Part 2, pp. 89-92.

4. Kudrina, O. Yu. (2013), "Innovation as a motive resource for the renewal of industrial potential of post-Soviet Ukraine" ["Innovatsiyi - yak rushiynyy resurs vidnovlennya promyslovoho potentsialu postradyans'koyi Ukrayiny"] Investytsiyi: praktyka ta dosvid, No 8, pp. 129-131.

5. Kudrina, O. Yu. (2014), Potencjał produkcyjny i jego rola w gospodarce regionu, Wybrane problemy zarządzania zrównoważonym rozwojem, pp. 42-50.

6. Mindlin, Yu. B. (2012), "Leading clusters role in economy" ["Providna rol' klasteriv v ekonomitsi"], NB: Ekonomika, trendy i keruvannya, No 1, pp. 1-5, available at: http://e-notabene.ru/etc/article 458.html

7. Pankova, L. I. (2014), "The genesis of theories of innovative labour and innovative clusters development" ["Henezys teoriy rozvytku innovatsiynoyi pratsi ta innovatsiynykh klasteriv"] Zbirnyk naukovykh prats' Cherkas'koho derzhavnoho tekhnolohichnoho universytetu. Seriya: Ekonomichni nauky, 37 (II), ChDTU, Cherkasy, pp. 65-70.

8. Pankova, L. I. (2014), "Economic interests of clustering processes diagnostication" ["Ekonomichni interesy diahnostuvannya protsesiv klasteryzatsiyi"], Visnyk Donets'koho universytetu ekonomiky ta prava, No 2, DonUEP, Donets'k, pp. 82-89. 
9. Finahina, O. V. and Zhurba, I. O. (2015), The development of cluster policy bases regional and branch prospects [Rozvytok zasad klasternoyi polityky: rehional'ni ta haluzevi perspektyvy]. In: Theoretical and applied aspects of sustainable development [Teoretychni ta prykladni aspekty staloho rozvytku[,Kondor-Vydavnytstvo, Kyiv, 316 p.

10. Galbraith, J. K. (2004), The new industrial state, available at: http://gtmarket.ru/laboratory/basis/5021

\section{Список використаної літератури}

1. Кластери в системі стратегії та тактики розвитку регіону : [монографія] / Л. В. Батченко, Е. О. Васильконова, А. В. Гуренко та ін. - Донецьк : ВІК, 2013. - 287 с.

2. Белозубенко В. С. Формирование инновационной системы Европейского Союза / В. С. Белозубенко, А. О. Горина, О. В. Абрашка // Бізнес-інформ: наук. журн. - 2013. - № 5. - С. 8-12.

3. Вартанова О.В. Бенчмаркінг інноваційного потенціалу промислового підприємства / О.В.Вартанова, I. В. Шестер // Науковий вісник Херсонського державного університету. - 2014. - № 8, ч. 2. - С. 89-92. (Серія «Економічні науки»).

4. Кудріна О. Ю. Інновації - як рушійний ресурс відновлення промислового потенціалу пострадянської України / О. Ю. Кудріна // Інвестиції: практика та досвід. - 2013. - № 8. - С. 129-131.

5. Кудріна О. Ю. Potencjał produkcyjny i jego rola w gospodarce regionu / О. Ю. Кудріна // Wybrane problemy zarządzania zrównoważonym rozwojem. - 2014. - P. 42-50.

6. Міндлін Ю. Б. Провідна роль кластерів в економіці [Електронний ресурс] / Ю. Б. Міндлін // NB: Економіка, тренди і керування. - 2012. - № 1. - С. 1-5. - Режим доступу : http://e-notabene.ru/etc/article 458.html

7. Панкова Л. І. Генезис теорій розвитку інноваційної праці та інноваційних кластерів / Л. І. Панкова // Збірник наукових праць Черкаського державного технологічного університету. - Вип. 37, ч. II. - Черкаси : ЧДТУ, 2014. - С. 65-70. - (Серія «Економічні науки»).

8. Панкова Л. І. Економічні інтереси діагностування процесів кластеризації / Л. І. Панкова // Вісник Донецького університету економіки та права : зб. наук. пр. - № 2. - Донецьк : ДонУЕП, 2014. - С. 82-89.

9. Фінагіна О. В. Розвиток засад кластерної політики: регіональні та галузеві перспективи / О. В. Фінагіна, I. О. Журба // Теоретичні та прикладні аспекти сталого розвитку : [кол. монографія]. - К. : КондорВидавництво, 2015. - $316 \mathrm{c}$.

10. Гэлбрейт Дж. Новое индустриальное общество [Электронный ресурс] / Дж. Гэлбрейт ; Центр гуманит. технологий. - М., 2004. - Режим доступа : http://gtmarket.ru/laboratory/basis/5021

\section{К. Андрссва}

\section{КОНЦЕПТУАЛЬНІ ЗАСАДИ РОЗВИТКУ ІННОВАЦІЙНИХ КЛАСТЕРІВ}

Статтю присвячено актуальним питанням розвитку регіонального менеджменту і накопиченню знань з питань формування концептуальних засад організації та підтримки інноваційних кластерів. Доведено, щзо розробка інноваційно-кластерної моделі украйнської економіки одночасно враховує і використовує низку концептуальних положень. Це взаємопов'язані положення сучасної теорії інновачій, постулати ринкової економіки, методики і технології регіонального менеджменту. Обтрунтовано, що конщептуальні положення розвитку інноваційних кластерів забезпечують прогрес та системність змін у веденні господарської діяльності в регіонах, такий результат є логічним і відповідним до таких стратегічних перспектив.

Окреслено ключові проблеми формування концепиії та моделі кластерів у регіональних та галузевих утвореннях з інновачійною орієнтаиією. Визначено бачення особливостей інновачійного кластеру з позичї інтеграційних та організаџійних процесів; галузевої спеціалізації та ринкових пріоритетів. Обтрунтовано ідею, мету, завдання, управлінські механізми та інструменти діяльності, підходи до оиінювання ефективності та результативності кластеру. Підходами і технологіями розвитку рекомендовано визнавати: всеохоплююче і якісне наукове та інформачійне забезпечення процесу вироблення рішень керівництвом; контроль над ефективністю та облік позитивних і негативних наслідків поточних рішень; відкритість і прозорість у колективних діях, вироблення рішень з урахуванням позицій усіх учасників кластеру; формування позитивного впливу на імідж регіону та галузі. Надано визначення ключових принципів інтегрованої кластерної співпраці.

Ключові слова: інновація, кластер, регіональний менеджмент, інноваційний менеджмент, кониепиія, мережа.

Рецензенти: д.е.н., професор Фінагіна О. В., завідувач кафедри менеджменту, Черкаський державний технологічний університет; д.е.н., професор Кратт О. А., Кременчуиький наиіональний уныверситет ымм. Михайла Остроградського. 